\title{
Comments to the Onlife Manifesto
}

\author{
Ugo Pagallo
}

$\S 0$. I love the "Onlife Manifesto," although I still have some problems with it. Of course, this is understandable since other manifestos had, say, only two authors, such as that of Friedrich Engels and Karl Marx, whilst our manifesto has more than twelve mothers and fathers. To cut to the chase, let me insist on two of my problems.

$\S 1.1$ First, it is all about our understanding of the past and, hence, the very notion of "modernity." I do agree that some assumptions of modernity are simply dead and, yet, thinking about the work of Spinoza, or of Leibniz, rather than Descartes and some advocates of the Enlightenment, I would say "Modernity is dead" and, still, long live Modernity and some of its venerable fruits! In Heideggerian terms, we should conceive the past as a matter of Gewesenheit, rather than Vergangenheit: Zuhanden, rather than passé depassé (Heidegger 1996). This different way of grasping what is gone reverberates on how we intend to address and project the future, namely the second of my problems: "this Manifesto aims to start a reflection on the way in which a hyperconnected world calls for rethinking the referential frameworks on which policies are built" (see the preface).

$\S 4.6$ Whilst the conclusion of our Manifesto mentions the relevance of "default settings and other designed aspects of our technologies," in order to "respect and protect attentional capabilities," we should have further insisted on this point, so as to test our debt to Modernity and, hence, to assess what is specific to the normative dimension of our concept reengineering exercise. Modernity has bequeathed to us the very idea of limited and accountable government, much as the notion of constitutional rule of law. Still, over the past decades, an increasing number of issues have become systemic and constitutional powers of national governments have been joined - and even replaced in a sort of Hegelian Aufhebung - by the network of competences and institutions summed up by the ideas of governance, good governance, and good enough governance. This has been a U.N.'s hot topic since the last 1990s and, correspondingly, this is why I review many of these challenges in my chapter in this volume: indeed, the time is ripe to address what is specific to the

\author{
U. Pagallo $(\varangle)$ \\ University of Torino, Torino, Italy \\ e-mail: ugo.pagallo@unito.it


good onlife governance, namely the evolutionary processes of spontaneous orders and multi-agent systems that:

1. Are ICTs-dependent and ubiquitous, that is, transnational; and,

2. Ultimately cannot be reduced to traditional political planning, i.e., the taxis-side of the law.

In addition to the usual hard and soft law-tools of governance, such as national rules, international treaties, or codes of conduct, I am convinced that particular attention should be drawn to the governance actors sub specie game designers: the governance of complex multi-agent systems interacting "onlife" does increasingly hinge on the technicalities of design mechanisms (Pagallo 2012a, b).

Open Access This chapter is distributed under the terms of the Creative Commons Attribution Noncommercial License, which permits any noncommercial use, distribution, and reproduction in any medium, provided the original author(s) and source are credited.

\section{References}

Heidegger, M. 1996. Being and time. Trans. Joan Stambaugh. Albany: State University of New York Press.

Pagallo, U. 2012a. Complex systems, simple laws: A normative approach to ICTs and the internet. In Politiques publiques, systèmes complexes, ed. Danièle Bourcier, Romain Boulet e Pierre Mazzega, 93-105. Paris: Hermann.

Pagallo, U. 2012b. Cracking down on autonomy: Three challenges to design in IT law. Ethics and Information Technology 14 (4): 319-328. 